\title{
EFFECTS OF FEEDING LAYING HENS DIETS SUPPLEMENTED WITH OMEGA 3 FATTY ACIDS ON THE EGG FATTY ACID PROFILE
}

\section{D. Šefer ${ }^{1}$, A. Andonov ${ }^{2}$ S. Šobajić ${ }^{3}$, R. Marković ${ }^{1}$, S. Radulović ${ }^{1}$, D. Jakić-Dimić $^{4}$ B. Petrujkić ${ }^{1}$}

${ }^{1}$ Faculty of Veterinary Medicine, Belgrade University, Boul. Oslob. 18, 11000 Belgrade, Republic of Serbia

2“"Grinagro” Skopje, Macedonia, Turisticka 73 1/21, 6000 Ohrid, Macedonia

${ }^{3}$ Faculty of Pharmacy, University of Belgrade, Vojvode Stepe 450, Belgrade, Republic of Serbia

${ }^{4}$ Veterinary Scientific Institute, Vojvode Toze 14, Belgrade, Republic of Serbia.

Corresponding author: dsefer@vet.bg.ac.rs

Original scientific paper

Abstract: In order to investigate the effects of omega (n) 3 fatty acids on egg quality a group-control trial was organized. Trial lasted 40 days and was performed in production conditions. Total number of 1264 laying hens of Lohman Brown classic provenience were used and randomly allotted into one of four groups by 316 hens each (C-control, I experimental, II experimental and III experimental). All groups of hens were fed diets of standard ingredients and chemical composition, while feed of I, II and III experimental group of hens was supplemented with micro algae Schizochytrium spp. (DHA Gold ${ }^{\circledR}$, Martek, USA) as a source of $n-3$ fatty acids in amount of $0.5,0.7$ and $1.0 \%$ respectively. In order to investigate the influence of micro algae Schizochytrium spp. feed supplementation on egg quality, from the aspect of content and ratio of fatty acids, random egg samples $(n=10)$ were taken at the $10^{\text {th }}, 20^{\text {th }}$ and $40^{\text {th }}$ day of the trial from each group. Egg yolk fatty acid content was determined by gas chromatography on Varian 1400 with flame ionization detector (FID detector) (on a packed column 20\% LAC-3R-728 Chromosorb WAW 80-100 mesh). Significant differences in egg yolk fatty acid content as well as their ratio were determined between treatment groups. Positive influence of supplemented micro algae preparation was observed. Highest content of n-3 poly unsaturated fatty acids (PUFA n-3) was determined in egg yolks of III experimental group while lowest content was determined in egg yolks of control group of hens. Micro algae feed supplementation, at the end of the trial period, positively affected egg yolk PUFA n-6/PUFA n-3 ratio, since determined ratio of 4.24 in III experimental group was more desirable than 12.27 determined in a control group. Marine algae (Schizochytrium spp.) feed supplementation in laying hens in amounts above $0.5 \%$ significantly affected egg yolk fatty acid composition as well as ratio of n-6/n-3 
PUFA. These findings support its use from nutritive, medical and economic point of view.

Key words: egg quality, fatty acids, feed, laying hen, DHA

\section{Introduction}

Evidence has grown to support a role for the increased consumption of n-3 polyunsaturated fatty acids (PUFAs) in the prevention of cardiovascular disease in humans (Kris-Etherton et al., 2002; Harper and Jacobson, 2005). In a summary statement published by the Nutrition Committee of the American Heart Association, patients without documented cardiovascular disease were recommended to consume oily fish twice a week and include oils or foods rich in $\alpha$-linolenic acid (ALA). Patients with documented chronic heart disease were encouraged to focus on their specific intake of docosahexaenoic acid (DHA) and eicosapentaenoic acid (EPA), targeting $1 \mathrm{~g}$ day-1 from oily fish (Kris-Etherton et al., 2002). Plant and animal fats contain relatively minor levels of $n-3$ fatty acids, with the exception of those plant oils that are rich in ALA, such as flax and canola. In order to obtain products which contain long chain n-3 PUFA, additional approaches are necessary. One example of such an approach is the production of $n$ 3 enriched egg.

The current practice of producing $n-3$ fatty acid-enriched eggs is primarily achieved by feeding laying hens' flaxseed rich in the n-3 fatty acid ALA. In general, the production practices have been standardized to yield eggs proportionally richer in ALA, as well as in DHA, as laying hens have the ability to convert ALA to DHA (Gonzalez-Esquerra and Leeson, 2001). However, flaxbased diets do not yield EPA-enriched eggs and significant enrichment of eggs with EPA entails the inclusion of marine oils (fish oil, fish meal). Nevertheless use of marine/fish meals and oils in laying hen diets has raised the concern related to "fishy odours" and "fishy off-flavours" which are considered to be the major undesirable side-effect when including high n-3 levels in diets fed to hens (Parpinello et al., 2006). Research has shown that single cell marine thraustochytrid algae, such as Schizochytrium spp. and other close related species, are promising alternative sources of LC-PUFAs (Barclay et al., 1994; Harel et al., 2002). These microalgae can be grown heterotrophically and are commercially available as dried products. They are rich in LC-PUFAs and considered a sustainable source of these essential fatty acids (EFAs). Feeding dried algae increases n-3 LCPUFAs in breast meat of broiler chickens (Mooney et al., 1998) and in milk of dairy cows (Franklin et al., 1999). Oil obtained from micro-algae Schizochytrium spp. is approved for human use as a novel food with a Commission Decision 2009/778/EC . 
The objective of this study was to evaluate the influence of feed supplemented with marine algae (Schizochytrium spp.) on egg fatty acid profile.

\section{Materials and Methods}

One-thousand-two-hundred-sixty-four laying hens of Lohman Brown classic provenience were used in the trial. Hens were randomly allotted into one of four groups with 316 hens each (C-control, I experimental, II experimental and III experimental). Trial which lasted 40 days was performed in semi-controlled environmental conditions with exposure to a 16-h photoperiod. Feed and water were provided ad libitum. Individual cage feeders were fitted with a metallic mesh screen $(1.5 \mathrm{~cm} \times 1.5 \mathrm{~cm}$ mesh size $)$ complete with weights that, when placed on top of the feed, minimized feed wastage.

All groups of hens were fed with diets of standard ingredients and chemical composition, which have completely satisfied the nutritional needs for commercial laying hens as set by the NRC (1994). Feed of I, II and III experimental group of hens in relation to feed of control group of hens was supplemented with micro algae Schizochytrium spp. (DHA Gold ${ }^{\circledR}$, Martek, USA) as a source of $\omega-3$ fatty acids in amount of $0.5,0.7$ and $1.0 \%$ respectively. Chemical and raw composition of feed is given in Table 1 .

Table 1. Raw and chemical composition of pig feed of control and experimental group

\begin{tabular}{|c|c|c|c|c|}
\hline & Control & I experimental & II experimental & III experimental \\
\hline Ingredient & $\%$ & $\%$ & $\%$ & $\%$ \\
\hline *DHA Gold ${ }^{(\mathbb{R}}$ & - & 0.50 & 0.70 & 1.00 \\
\hline Corn & 57.72 & 57.22 & 57.02 & 56.72 \\
\hline Wheat bran & 5.50 & 5.50 & 5.50 & 5.50 \\
\hline Soybean meal (44\% CP) & 23.34 & 23.34 & 23.34 & 23.34 \\
\hline DL Methionine & 0.09 & 0.09 & 0.09 & 0.09 \\
\hline Choline chloride & 0.05 & 0.05 & 0.05 & 0.05 \\
\hline Limestone & 9.70 & 9.70 & 9.70 & 9.70 \\
\hline Monocalcium phosphate & 0.77 & 0.77 & 0.77 & 0.77 \\
\hline $\mathrm{NaCl}$ & 0.33 & 0.33 & 0.33 & 0.33 \\
\hline Unrefined sunflower oil & 2.00 & 2.00 & 2.00 & 2.00 \\
\hline Vitamin - mineral premix & 0.50 & 0.50 & 0.50 & 0.50 \\
\hline \multicolumn{5}{|l|}{ Chemical composition } \\
\hline Crude fibre(\%) & 3.50 & 3.47 & 3.47 & 3.47 \\
\hline Crude protein $(\mathrm{CP})(\%)$ & 15.50 & 15.44 & 15.42 & 15.40 \\
\hline Crude fat $(\%)$ & 4.94 & 4.92 & 5.00 & 5.00 \\
\hline $\mathrm{Ash}(\%)$ & 13.00 & 13.00 & 13.00 & 13.00 \\
\hline Metabolic energy $\mathrm{MJ} / \mathrm{kg}$ & 11.50 & 11.50 & 11.50 & 11.50 \\
\hline
\end{tabular}

${ }^{*}$ DHA Gold ${ }^{\circledR}$ contains minimal level of $17 \%$ DHA omega -3 . 
Influence of micro algae Schizochytrium spp. feed supplementation on egg content and ratio of fatty acids was investigated. Egg samples $(n=10)$ were taken randomly at the $10^{\text {th }}, 20^{\text {th }}$ and $40^{\text {th }}$ day of the trial from each group of hens. Egg yolk fatty acid content was determined by gas chromatography on Varian 1400 with FID detector (on a packed columns 20\% LAC-3R-728 Chromosorb WAW 80100 mesh). Fatty acid identification was done by retention time comparation with standards (Lipid standards, Sigma-Aldrich St. Louis, MO, USA). Statistical processing of data was done by method of variance analysis (ANOVA) according to Snedecor and Cohran (1971), and significance of differences of arithmetic means by t-test. Software package PrismaPad v.4.0 was used for statistical calculation.

\section{Results and Discussion}

Observed differences in content as well as in $\omega-6 / \omega-3$ fatty acid ratio of egg yolk between different treatments were significant. Results are shown in Table 2.

Table 2. Fatty acid content of egg yolk (\% of total fat)

\begin{tabular}{|c|c|c|c|c|c|c|c|c|c|c|c|c|}
\hline $\overrightarrow{\tilde{\theta}}$ & 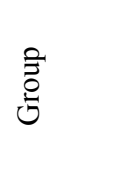 & 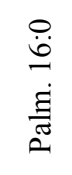 & $\begin{array}{l}\stackrel{0}{\dot{\infty}} \\
\stackrel{\dot{D}}{\dot{S}}\end{array}$ & 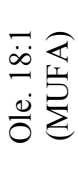 & 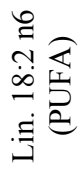 & 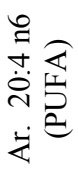 & 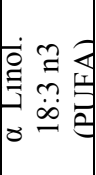 & 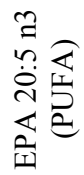 & 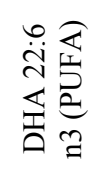 & 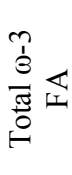 & 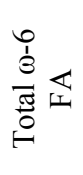 & 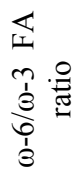 \\
\hline 0 . & All groups & 20.60 & 18.30 & 35.5 & 18.40 & 2.90 & 0.50 & 0.17 & 0.40 & 1.07 & 21.30 & 19.91 \\
\hline \multirow{4}{*}{10.} & Control & 19.80 & 18.60 & 36.00 & 18.70 & 2.80 & 0.60 & 0.10 & 0.40 & 1.10 & 21.50 & 19.55 \\
\hline & $I \exp$ & 22.40 & 13.30 & 36.70 & 19.20 & 3.10 & 0.65 & 0.15 & 1.35 & 2.15 & 22.30 & 10.37 \\
\hline & II exp & 18.80 & 17.10 & 38.60 & 17.60 & 2.40 & 0.35 & 0.10 & 2.60 & 3.05 & 19.40 & 6.36 \\
\hline & III $\exp$ & 18.90 & 16.00 & 38.00 & 17.50 & 2.90 & 0.45 & 0.10 & 3.20 & 3.75 & 20.40 & 5.44 \\
\hline \multirow{4}{*}{20.} & Control & 18.10 & 17.50 & 38.00 & 19.30 & 3.00 & 0.56 & 0.20 & 0.50 & 1.26 & 22.30 & 17.70 \\
\hline & $I \exp$ & 18.40 & 16.30 & 39.90 & 17.90 & 2.80 & 0.45 & 0.15 & 1.75 & 2.35 & 20.70 & 8.81 \\
\hline & II exp & 18.70 & 16.90 & 39.20 & 16.30 & 2.80 & 0.40 & 0.23 & 2.60 & 3.23 & 19.10 & 5.91 \\
\hline & III exp & 18.20 & 18.00 & 36.30 & 17.30 & 3.10 & 0.50 & 0.20 & 3.80 & 4.50 & 20.40 & 4.53 \\
\hline \multirow{4}{*}{40} & Control & 17.40 & 16.70 & 42.30 & 16.10 & 2.30 & 0.55 & $0.25^{\mathrm{ab}}$ & $0.70^{\mathrm{aAB}}$ & 1.50 & 18.40 & 12.27 \\
\hline & I exp & 17.90 & 17.30 & 38.10 & 17.90 & 2.90 & 0.35 & $0.10^{\mathrm{a}}$ & $1.95^{\mathrm{aA}}$ & 2.40 & 20.80 & 8.67 \\
\hline & II exp & 16.00 & 18.30 & 36.60 & 18.00 & 2.60 & 0.50 & 0.20 & $2.85^{\mathrm{aBC}}$ & 3.55 & 20.60 & 5.80 \\
\hline & III exp & 16.40 & 16.60 & 37.50 & 17.30 & 3.50 & 0.70 & $0.10^{\mathrm{b}}$ & $4.10^{\mathrm{aAC}}$ & 4.90 & 20.80 & 4.24 \\
\hline
\end{tabular}

a $\quad P<0.05$

A-C $\quad P<0.01$

Palm. 16:0

Ste. 18:0

Ole. 18:1 (MUFA)

Lin. 18:2 n6 (PUFA)

Ar. 20:4 n6 (PUFA)

Palmitic acid 16:0

Stearic acid 18:0

Oleic acid 18:1 Mono Unsaturated Fatty Acid (MUFA)

Linolic acic 18:2 n6 Poly Unsaturated Fatty Acid (PUFA)

Arachidonic acid 20:4 n6 Poly Unsaturated Fatty Acid (PUFA) 
$\alpha$ Linol. 18:3 n3 (PUFA)

EPA 20:5 n3 (PUFA)

DHA 22:6 n3 (PUFA)

Total $\omega-3$ FA

Total $\omega-6$ FA

$\omega-6 / \omega-3$ FA ratio $\alpha$ Linoleic 18:3 n3 Poly Unsaturated Fatty Acid (PUFA)

Eicosapentaenoic acid 20:5 n3 Poly Unsaturated Fatty Acid (PUFA)

Docosahexaenoic acid 22:6 n3 Poly Unsaturated Fatty Acid (PUFA)

Total $\omega-3$ Fatty Acids

Total $\omega-6$ Fatty Acids

$\omega-6 / \omega-3$ Fatty Acid ratio

DHA (algae product) supplementation had positively affected content of egg yolk $\omega-3$ fatty acids. On the end of the trial (day 40) highest content of $\omega-3$ fatty acids $(4.9 \%)$ was determined in III experimental group while lowest value was observed in control group (1.5\%). Beside that, ratio of $\omega-6 / \omega-3$ fatty acids in egg yolk was more desirable in III experimental group (4.24) compared to control group of hens (12.27). Obtained results are in accordance with the results of other authors that have used marine oils to generate long chain n-3 PUFA enriched eggs with success (Gonzalez-Esquerra and Leeson, 2001; Alvarez et al., 2004; Cachaldora et al., 2006). As previously documented (Gonzalez-Esquerra and Leeson, 2001), in the production of long chain n-3 fatty acid-enriched eggs, three general approaches have been used: (1) the inclusion of marine oils or meals high in EPA and DHA (Van Elswyk et al., 1995; Gonzalez- Esquerra and Leeson, 2000); (2) the inclusion of ingredients, such as flax or canola, high in ALA (Cherian and Sim, 1991; Caston et al., 1994); and (3) the inclusion of algal oils high in DHA (Herber and Van Elswyk, 1996). While the available data support all three approaches for increasing the total n-3 content of eggs, the obtained amounts of the individual n-3 fatty acids (ALA, EPA, docosapentaenoic acid (DPA) and DHA) were different.

DHA levels in eggs, recorded in current study, increased in a linear fashion, with the highest level recorded in hens whose diet was fortified with $1 \%$ DHA Gold ${ }^{\circledR}$ and lowest in control group. These data are in agreement with the findings of Gonzalez-Esquerra and Leeson (2000), who also demonstrated a linear incorporation of long chain n-3 fatty acids into eggs with increasing dietary concentrations of menhaden oil. The use of algal oils high in DHA lead to increased total DHA in the egg (from 35 to $172 \mathrm{mg} / \mathrm{egg}$ ), with DHA represented $94 \%$ of the total n-3 content of the yolk (Herber and Van Elswyk, 1996). Using a stabilized fish oil product, with an EPA to DHA ratio of 1.13, at an inclusion rate of $30 \mathrm{~g} / \mathrm{kg}$ diet, Millet et al. (2006) observed increases in both EPA (from 0.28 to $0.91 \mathrm{mg} / \mathrm{g}$ yolk) and DHA (from 3.7 to $8.8 \mathrm{mg} / \mathrm{g}$ yolk), relative to control diets where animal fat was the predominant lipid source. Increase of DHA observed in our study gains even greater significance since recommendations for the patients with documented cardiovascular diseases are to focus on specific intake of docosahexaenoic acid (DHA) and eicosapentaenoic acid (EPA) (Kris-Etherton et al., 2002). However, EPA levels determined in our trial were not positively affected by algal product feed supplementation and even more were inconsistent. Others have reported either no change (Van Elswyk et al., 1995) or, in fact, lower DHA and EPA levels (Huang et al., 1990) in response to increasing menhaden oil in the laying hen diet. Differences in the efficiency of incorporation of long chain 
n-3 fatty acids into the yolk lipids may be related to the impact that diet and ingredient composition have on the efficiency of fatty acid biotransformation (Gonzalez-Esquerra and Leeson, 2001). For the current study, dietary treatments were balanced for energy, total lipid and all non-lipid components (starch, nonstarch polysaccharides, minerals, etc.). The inclusion of DHA Gold ${ }^{\circledR}$ (I, II and III experimental group) was made at the expense of corn. Under the conditions of the current study, linear increases in long chain n-3 fatty acids were evident. The total content of the n-3 fatty acids increased from 1.50 to $4.90 \%$ of total fat as the DHA Gold $^{\circledR}$ increased from 0 to $1 \%$ diet. These findings are in accordance to the findings of Gonzalez-Esquerra and Leeson (2000), who reported a linear incorporation of long chain n-3 fatty acids into eggs with increasing dietary concentrations of menhaden oil.

\title{
Conclusion
}

The inclusion of algal product (DHA Gold ${ }^{\circledR}$ ) at levels up to $1 \%$ in the laying hen diet lead to significant increases in the DHA but not in EPA content of eggs, with no evidence of plateaux being reached. Positive effect was more pronounced with inclusion of higher concentrations of algal product. Use of $\omega-3$ fatty acids gives an opportunity to produce designed omega 3 rich eggs with more desirable $\omega-6 / \omega-3$ ratio, compared to conventionally produced eggs. Therefore the use of $\omega-3$ fatty acids as a feed supplement has nutritive, medical and economical approval.

\section{Acknowledgment}

This work was supported by Grant No III 46002 Ministry of Education and Science, Republic of Serbia.

\section{Efekat ishrane kokoši nosilja smešama obogaćenim omega-3 masnim kiselinama na sastav masnih kiselina u jajetu}

\author{
D. Šefer, A. Andonov, S. Šobajić, R. Marković, S. Radulović, D. Jakić-Dimić, B. \\ Petrujkić
}

Rezime

Da bi se ispitao uticaj omega -3 masnih kiselina na kvalitet jaja postavljen je ogled sa tri eksperimentalne i jednom kontrolnom grupom. Ogled je trajao 40 dana i sproveden je u proizvodnim uslovima. Ukupan broj od 1264 kokoši nosilja Lohmann Brown classic provenijence je slučajno raspoređen u četiri grupe po 316 
nosilja u svakoj (C-kontrola, I eksperimentalna, II eksperimentalna i III eksperimentalna).

Sve grupe su hranjene smešama standardnog sastava, dok su eksperimentalne grupe I, II, III hranjene smešom obogaćenom mikroalgama Schizochytrium spp. (DHA Gold ${ }^{\circledR}$, Martek, USA) kao izvorom n-3 masnih kiselina u količini od 0,$5 ; 0,7 ; 1,0$.

U cilju ispitivanja hrane obogaćene mikroalgom Schizochytrium spp. na kvalitet jaja sa aspekta sadržaja i odnosa masnih kiselina, uzet je slučajan uzorak jaja $(n=10)$ 10., 20., i 40. dana iz svake grupe. Sadržaj masnih kiselina u žumancetu je određen gasnim hromatografom Varian 1400 sa plamen jonizujućim detektorom (FID detector) (na koloni 20\% LAC-3R-728 Chromosorb WAW 80-100 mreža).

Značajne razlike u sadržaju masnih kiselina u žumancetu kao i njihov odnos su određeni između tretmana. Najveći sadržaj n-3 polinezasićenih masnih kiselina (PUFA n-3) određen je u žumancetu jaja treće eksperimentalne grupe, dok je najmanji sadržaj određen u kontrolnoj grupi. Dodavanje mikro algi smešama na kraju oglednog perioda, pozitivno je uticao na odnos PUFA n-6/PUFA n-3 u žumancetu, pošto je određen odnos od 4,24 u III eksperimentalnoj grupi što je poželjnije od 12,27 koliko je određeno u kontrolnoj grupi.

Dodavanje morskih algi (Schizochytrium spp.) u smeše za kokoši nosilje u koncentraciji oko $0,5 \%$, značajno je uticalo na sastav masnih kiselina u žumancetu jajeta kao i na odnos n-6/n-3 PUFA. Ovi rezultati opravdavaju upotrebu algi u ishrani kokoši nosilja sa nutritivne, medicinske i ekonomske tačke gledišta.

\section{References}

ALVAREZ C., CACHALDORA P., MÉNDEZ J., GARCÍA-REBOLLAR P., DE BLAS J.C. (2004): Effects of dietary conjugated linoleic acid and fish oil supplementation on performance and egg quality in laying hens. Br. Poult. Sci., 45, 524-529.

BARCLAY W.R., MEAGER K.M., ABRIL J.R. (1994): Heterotrophic production of long chain omega-3 fatty acids utilizing algae and algae-like microorganisms. J. Appl. Phycol., 6, 123-129

CACHALDORA P., GARCÍA-REBOLLAR P., ALVAREZ C., DE BLAS J.C., MÉNDEZ J. (2006): Effect of type and level of fish oil supplementation on yolk fat composition and n-3 fatty acids retention efficiency in laying hens. Br. Poult. Sci., 47, 43-49.

CASTON L., SQUIRES E.J., LEESON S. (1994): Hen performance, egg quality, and sensory evaluation of eggs from SCWL hens fed dietary flax. Can. J. Anim. Sci., 74, 347-353.

CHERIAN G., SIM J.S. (1991): Effect of feeding full fat flax and canola seeds to laying hens on the fatty acid composition of eggs, embryos, and newly hatched chicks. Poult. Sci., 70, 917-922. 
FRANKLIN S.T., MARTIN K.R., BAER R.J., SCHINGOETHE D.J., HIPPEN A.R. (1999): Dietary marine algae (Schizochytrium sp.) increases concentrations of conjugated linoleic, docosahexaenoic and transvaccenic acids in milk of dairy cows. J. Nutr., 129, 2048-2052.

GONZALEZ-ESQUERRA R., LEESON S. (2000): Effect of feeding hens regular or deodorized menhaden oil on production parameters, yolk fatty acid profile, and sensory quality of eggs. Poult. Sci., 79, 1597-1602.

GONZALEZ-ESQUERRA R., LEESON S. (2001): Alternatives for enrichment of eggs and chicken meat with omega-3 fatty acids. Can. J. Anim. Sci., 81, 295-305.

HAREL M., KOVEN W., LEIN I., BAR Y., BEHRENS P., STUBBLEFIELD J., ZOHAR Y., PLACE A.R. (2002): Advanced DHA, EPA and ArA enrichment materials for marine aquaculture using single cell heterotrophs. Aquaculture, 213, 347-362.

HARPER C.R., JACOBSON T.A. (2005): Usefulness of omega-3 fatty acids and the prevention of coronary heart disease. Am. J. Cardiol., 96, 1521-1529.

HERBER S.M., VAN ELSWYK M.E. (1996): Dietary marine algae promotes efficient deposition of $n-3$ fatty acids for the production of enriched shell eggs. Poult. Sci., 75, 1501-1507.

HUANG Z.B., LEIBOVITZ H., LEE C.M., MILLER R. (1990): Effect of dietary fish oil on omega-3 fatty acid levels in chicken eggs and thigh flesh. J. Agric. Food Chem., 38, 743-747.

KRIS-ETHERTON P.M., HARRIS W.S., APPEL L.J. (2002): Fish consumption, fish oil, omega-3 fatty acids, and cardiovascular disease. Circulation, 106, 27472757.

MILLET S., DE CEULAER K., VAN PAEMEL M., RAES K., DE SMET S., JANSSENS G.P.J. (2006): Lipid profile in eggs of Araucana hens compared with Lohmann selected Leghorn and ISA Brown hens give diets with different fat sources. Br. Poult. Sci., 47, 294-300.

MOONEY J.W., HIRSCHLER E.M., KENNEDY A.K., SAMS A.R., VAN ELSWYK M.E. (1998): Lipid and flavour quality of stored breast meat from broilers fed marine algae. J. Sci. Food Agric., 78, 134-140.

NRC. (1994): Nutrient Requirements of Poultry. 9th ed. Natl. Acad. Press, Washington, DC.

PARPINELLO G.P., MELUZZI A., SIRRI F., TALLARICO N., VERSARI A. (2006): Sensory evaluation of egg products and eggs laid from hens fed diets with different fatty acid composition and supplemented with antioxidants. Food Res. Int., 39, 47-52.

SNEDECOR G. W., COCHRAN W. C. (1971): Statistical Methods $6^{\text {th }}$ edition Iowa State Press, Ames.

VAN ELSWYK M.E., HARGIS B.M., WILLIAMS J.D., HARGIS P.S. (1995): Dietary menhaden oil influences sensory characteristics and head space volatiles of shell eggs. J. Food Sci., 60, 85-89. 